\title{
WASTEWATER CHARACTERISTICS IN PARTIALLY SEALED CESSPIT - CASE STUDY FROM BEIT DAJAN, PALESTINE
}

\author{
Nezar Al-Atawneh \\ Nidal Mahmoud ${ }^{1}$ \\ Institute of Environmental and Water Studies (IEWS), Birzeit University, P.O. Box \\ 14, Birzeit, the West Bank, Palestine \\ N. Peter van der Steen \\ Piet N.L. Lens \\ UNESCO-IHE Institute for Water Education, P.O. Box 3015, Delft, 2601 DA, \\ The Netherlands
}

\begin{abstract}
Raw domestic wastewater from an individual home was characterised and the water quality was followed after disposal to a partially sealed cesspit over the whole filling period of 4 months. The results revealed that raw wastewater was of medium strength according to the US EPA classification, and was more concentrated than Palestinian municipal sewage. Septage is the water accumulating in the pit, but above the accumulated bottom sludge. The septage was more concentrated than the raw sewage. The specific household water consumption, wastewater generated, septage collected by vacuum truck and septage water infiltration were respectively (59 L/c.d; 100\%), (52 L/c.d; 87\%), (11 L/c.d; 19\%) and (40 L/c.d; $68 \%)$. The specific removal of pollutants in the cesspits were: $\mathrm{BOD}_{5}(78 \mathrm{~g} / \mathrm{c} / \mathrm{d}), \mathrm{COD}(62 \mathrm{~g} / \mathrm{c} / \mathrm{d})$, $\mathrm{N}$ total $(52 \mathrm{~g} / \mathrm{c} / \mathrm{d}), \mathrm{PO}_{4}-\mathrm{P}(66 \mathrm{~g} / \mathrm{c} / \mathrm{d})$ and TSS $(69 \mathrm{~g} / \mathrm{c} / \mathrm{d})$. The specific pollution loads of emptied septage were BOD $_{5}(5.6 \mathrm{~g} / \mathrm{c} / \mathrm{d})$, COD $(19.3 \mathrm{~g} / \mathrm{c} / \mathrm{d}), \mathrm{N}$ total $(4.8 \mathrm{~g} / \mathrm{c} / \mathrm{d}), \mathrm{PO}_{4}-\mathrm{P}(0.17 \mathrm{~g} / \mathrm{c} / \mathrm{d})$ and TSS $(25.5 \mathrm{~g} / \mathrm{c} / \mathrm{d})$. The concentrations of heavy metals $(\mathrm{Cu}, \mathrm{Pb}, \mathrm{Mn}, \mathrm{Fe}$ and $\mathrm{Zn})$ in septage water were not in compliance with heavy metals concentration limits of the Palestinian regulations for wadi disposal and effluent reuse in agriculture. As a consequence, septage disposal in wadis and agricultural fields is not safe. However, according to municipal regulations, the heavy metals concentrations allow septage to be disposed in the Al-Bireh wastewater treatment plant septage receiving unit, to be further treated in the aerobic system. Regarding nitrogen that is removed in the cesspit, the vast majority will most likely exfiltrate out of the cesspit into the surrounding soil, and might potentially reach
\end{abstract}

\footnotetext{
${ }^{1}$ Corresponding author; E mail: nmahmoud@birzeit.edu
} 
Linnaeus ECO-TECH '14,

Kalmar, Sweden, November 24-26, 2014

the groundwater. Therefore, cesspits should be replaced by proper wastewater treatment systems.

\section{KEYWORDS}

Onsite treatment, Sewage, Cesspits, Heavy metals, Nitrogenous compounds, groundwater pollution.

\section{INTRODUCTION}

Sewage is the main pollution source on global scale. Deterioration of the public health can be caused due to the discharge of untreated wastewater into the aquatic environment. In some developing countries about $100 \%$ of the household wastewater is discharged untreated in water bodies or infiltrates to the ground water. The lack of proper on-site sanitation in unsewered lowincome areas is becoming an important source of nutrient-rich wastewater leaching to groundwater [1]. Also in Europe and the United States, the connection of dispersed human settlements like remote houses, summer houses, farms and recreation facilities to sewerage system is too costly, and is of serious concern [2, 3]. In developing countries, of limited technical and financial capabilities, primitive systems are used for wastewater management. Cesspits are amongst the most common on-site wastewater collection systems there. Cesspits are simple holes that are left without lining, so as to allow sewage infiltration into sub-soil to reduce the cost of frequent emptying. Treatment processes in permeable cesspits include wastewater settling, anaerobic sludge digestion and percolation of liquid into the subsurface where microbial action degrades part of the organic fraction. Cesspits are considered as non point sources of pollution that are widespread in many countries in the middle East, like Palestine, Jordan, Yemen, and others [4].

Cesspits systems are the most common treatment units on household level in rural areas of the West Bank and Gaza Strip. About 65\% of the annual domestic wastewater in Palestine is currently collected in cesspits, where inadequate disposal might cause cumulative public health risks and annual environmental degradation. Management practices for wastewater disposal in the West Bank are limited to the collection of wastewater by piped sewage networks and household cesspits [5]. It is estimated that around 41.17 MCM of wastewater is collected in cesspits that serve $68 \%$ of the Palestinian population in the West Bank [6]. Signals of groundwater pollution in Palestine have already been reported, e.g. $\mathrm{NO}_{3}$ more than $50 \mathrm{mg} / \mathrm{L}$. Adequate treatment and disposal of domestic septage are crucial to public health and the environment. The present practice of septage disposal in Palestine is mainly via an uncontrolled discharge in nearby wadis and open fields, and to a much lesser extent in public sewerage networks that might end up in the very few existing wastewater treatment plants. This type of disposal is uncontrolled and has several negative effects on both the sewerage system and the treatment processes.

At present, hardly any technical data are available in Palestine on domestic septage quantity and quality. Hence, it is important to know the characteristics and the volume of septage in order to handle and dispose of properly. These data are useful for operational and design purposes of existing or newly planned urban sewage treatment plants as well as determining optimal design values for its treatment and disposal [7]. Moreover, such data is crucial to assess the 
Linnaeus ECO-TECH '14,

Kalmar, Sweden, November 24-26, 2014

environmental impact of cesspits as a consequence of septage water infiltration and emptied septage disposal in open areas and wadis. Voigtländer et al. [8] reported that most planners forgot to include septage loads during the design phase, which later cause process failure especially in biological unit operations (aeration tanks, anaerobic reactors and trickling filters).

In addition to nitrogenous compounds, heavy metals likely to be present in septage are of environmental and health concern in Palestine. Heavy metals $(\mathrm{Zn}, \mathrm{Cu}, \mathrm{Pb}$ and $\mathrm{Ni}$ ) are a worldwide problem because these metals are indestructible and most of them have toxic effects on living organisms, and accumulate in reservoirs and enter the food chain [9, 10]. Heavy metals in household sewage might originate from feces, cleaners, paints, and wear and tear of utensils and equipment, eroding pipes, and runoff from roofs [11, 12].

Knowledge on sewage "treatment" in cesspits as anaerobic reactors is extremely limited. The degree of digestion of the solids in the cesspits have undergone will most likely depend on the frequency of pumping. Published literature [13, 14] indicated that septage quality could strongly differ from place to place as many factors influence the physic-chemical characteristics of septage. In Palestine, emphasis was given to characterize and quantify sewage collected in sewer networks $[15,16]$. But so far very little effort has been made to quantify the cesspits septage generation rate, characteristics and environmental impact in terms of emanated pollutants fluxes to the surface and under surface environments.

The quantity and quality of septage from cesspits is still not adequately tackled, yet crucial for the design of centralized sewage treatment plants, and also the assessment of pollution loads not only to the "planned wastewater treatment plants" but also to groundwater and open fields. The household raw sewage characteristics also need more insight, as it is likely to differ from domestic and municipal sewage collected in sewer networks from large communities, as it is crucial as the clearly the application of onsite wastewater management systems is inevitable worldwide. The potent pollutants fluxes are still to be addressed considering the dominance of the cesspits and the sensitivity of the groundwater aquifers. Although on a one hand, the cesspits are considered a major non point source of pollution in the West Bank, on the other hand it should be realized that the cesspit is in essence a unique type of anaerobic reactor as it is "partially" continuous, "partially" batch and "partially" accumulation system. The follow up of the course of pollutants alteration in terms of possible removal and conversion is crucial for predicting septage quality from the various types of cesspits with variable emptying rates (filling rates). There is still lack of data about the filling rate of cesspits and the incorporated changes in the sewage organic and inorganic content that occur within the cesspit during the filling period. Although the performance of onsite anaerobic reactors like septic tanks has been well documented, but to our knowledge there is still uncertainty surrounding the performance of cesspit as a biological reactor. There are numerous factors affecting the performance of onsite systems that have not yet been quantified. It is possible that some of these factors pertain to local customs and conditions such as diet and cleansing habits, in addition to the specific reactor technology features.

This research characterized the composition of modern single residential source onsite raw wastewater and primary treated effluent (cesspits). This research presents the results for the characterization of household raw domestic wastewater, and quantification of specific pollution 
load (g/c.d) and assessing the course of wastewater quality alteration in terms of $\mathrm{BOD}_{5}, \mathrm{COD}$, TKN, $\mathrm{PO}_{4}-\mathrm{P}$, TS, TSS, TDS, $\mathrm{pH}, \mathrm{EC}$ and heavy metals (Zn, $\mathrm{Cu}, \mathrm{Ni}, \mathrm{Pb}, \mathrm{Mn}, \mathrm{Fe}, \mathrm{Cr}$ ), in a partially sealed house onsite cesspit during the whole filling period of 4 months. Also, water and wastewater mass balance were quantified for a single household and finally the pollution fluxes from the studied cesspit percolated into the surrounding soil were assessed.

The main objectives of this research were to characterize the septage water of a partially sealed household cesspit over the filling period, with emphasis on organic matter $\left(\mathrm{BOD}_{5}, \mathrm{COD}\right.$ ), nitrogenous compounds (TKN, $\mathrm{NO}_{3}$ ) and heavy metals ( $\mathrm{Zn}, \mathrm{Cu}, \mathrm{Ni}, \mathrm{Pb}, \mathrm{Mn}, \mathrm{Fe}, \mathrm{Cr}$ ), in a partially sealed house onsite cesspit during the filing period; and to determine the specific pollution loads (g/c.d) and fluxes from the studied cesspit percolated into the surrounding soil of household cesspit through mass balance for a single household, in addition to identifying the Characterization of household raw domestic wastewater and quantification of specific pollution load (g/c.d) in the sub catchment area of Wadi Fara'a.

\section{MATERIAL AND METHODS}

\subsection{Experimental set-up}

\subsubsection{Cesspit}

An actual operating household cesspit, that is partially sealed with a filling period of a few months, was selected to carry out this research in the unsewered village of Beit Dajan in Palestine. While numerous subtleties exist between waste streams from a single residential source, care was taken to obtain test site that represented the general population in the study area. Higher occupancy was anticipated to increase the daily water use with variation in household contributions (toilet, laundry, bathing/showering).

\subsubsection{Raw wastewater collection and sampling tanks}

Graded tank was setup to separate and collect raw wastewater from the targeted household. Raw and wastewater from cesspit (septage water) were collected from a one household in Beit Dajan village located in the sub catchment area of Wadi Fara'a. During 120 days of continuous monitoring of septage water in the cesspit, samples were analyzed for $\mathrm{BOD}_{5}, \mathrm{COD}, \mathrm{TKN}$, $\mathrm{PO}_{4}-\mathrm{P}, \mathrm{TS}, \mathrm{TSS}, \mathrm{TDS}, \mathrm{pH}, \mathrm{EC}$ and fecal coliform.

A raw wastewater collection tank of $500 \mathrm{~L}$ working volume was installed in the yard of the selected study house. The tank was equipped with all of the polyvinyl chloride (PVC) pipelines needed for filling and emptying the raw wastewater. The household wastewater outlet pipes were re-arranged and connected to the installed collection tank. The tank was provided with water stopcock and measuring tape to measure daily the volume of collected wastewater.

\subsection{Raw wastewater collection and sampling}

Raw wastewater collection and sampling lasted for 14 consecutive days. The tank was allowed to be filled over 24 hours, and then a representative sample was taken after thoroughly mixing the tank content. After that, the volume of collected wastewater was measured, and then the tank was emptied to allow for repeating the cycle of daily collection and sampling. The wastewater 
Linnaeus ECO-TECH '14,

Kalmar, Sweden, November 24-26, 2014

temperature, Electrical Conductivity (EC) and $\mathrm{pH}$ were measured in situ. The collected sample was stored in a cooling box at $4{ }^{\circ} \mathrm{C}$, and directly transferred to the lab for analysis.

\subsection{Specific water consumption and wastewater production}

At the beginning of the research, the home water supply meter was recorded daily for 30 days, and similarly the volume of produced wastewater was measured.

\subsection{Cesspit start-up, operation and monitoring}

At the inset of this experiments, the cesspit content was emptied till reaching the bottom rather thick sludge layer. The dimensions of the cesspit were measured, using tape and a long stick. The reading of the water supply meter was recorded to allow for mass balance calculation over the cesspit once completely becoming full. A first "sludge" sample from the cesspit bottom was collected for analysis. Afterwards, septage samples from the cesspit were collected biweekly over the whole filling period, which was coincidently four months. The samples were collected, after well carefully scraping the very thin floating scum layer of a few millimeters, from different horizontal and vertical locations in the cesspit. The samples were preserved at $4{ }^{\circ} \mathrm{C}$ in special insulated box, and then transferred to the lab for analysis. The septage $\mathrm{pH}$, EC and temperature were measured in situ. The reading of the water supply meter was recorded daily, and the volume of collected wastewater was measured. The pollution fluxes from the cesspit were assessed based on mass balance by calculating the total volumes of influent sewage over the filling period and emptied sepatge when the cesspi was full.

\subsection{Analytical methods}

The collected samples of raw wastewater and septage were analyzed for total suspended solids (TSS), total solids (TS), total dissolved solids (TDS), kjeldahl-nitrogen (Kj-N), chemical oxygen demand (COD), biological oxygen demand (BOD) and total $\mathrm{PO}_{4}-\mathrm{P}$ according to standard methods (APHA, 1995). Also, the collected samples of septage and raw wastewater were analyzed for temperature, Electrical conductivity (EC), heavy metals ( $\mathrm{Cu}, \mathrm{Ni}, \mathrm{Pb}, \mathrm{Mu}, \mathrm{Fe}, \mathrm{Cr}$, $\mathrm{Zn}$ ) and $\mathrm{pH}$. Heavy metal concentrations were determined by ICP according to the stander method (ICP multi element stander solution 4 certiPUR lot- No. HC957274) atomic emission spectrometry (AES) (ICP OPTIMA 3000 Perkin Elemer), following acid digestion and using appropriate certified reference materials in addition to intra-laboratory standards.

\subsection{Calculations}

\section{Mass balance calculations}

Volume of percolated wastewater from the cesspit to the surrounding soil = volume of sewage produced over the filling period - emptied sewage volume

…...eq. 1

Specific raw pollutant production $\left(\frac{g}{c} / d\right)=\frac{\text { QinXCin }}{\text { nubmor of household inhabitants }}$

.....eq. 2

Specific septage pollutant production $\left(\frac{g}{c} / d\right)=\frac{\text { QoutXCout }}{\text { nubmor of household inhabitants }}$ 
Linnaeus ECO-TECH '14,

Kalmar, Sweden, November 24-26, 2014

Specific mass lost $\left(\frac{g}{c} / d\right)=\frac{\text { QinXCin-QoutXCout }}{\text { nubmor of household inhabitants }}$ .eq. 4

Where:

Mass lost: mass of a certain influent element that is removed in the cesspit (g/d)

$\mathrm{Q}_{\text {in }}$ and $\mathrm{Q}_{\text {out }}$ : volume of raw wastewater and emptied septage $(\mathrm{L} / \mathrm{d})$

$\mathrm{C}_{\text {in }}$ and $\mathrm{C}_{\text {out }}$ : concentration of a given parameter in the influent raw wastewater and in septage once the cesspit is filled and emptied $(\mathrm{g} / \mathrm{L})$

\section{RESULTS AND DISCUSSION}

\subsection{Individual home sewage characteristics}

\subsubsection{General}

The individual home wastewater characteristics were very sparsely investigated in literature. The results presented in Table 1 reveal that raw wastewater characteristics of an individual home in Beit Dajan is of medium strength and is relatively less concentrated than municipal. Mahmoud et al. [16] postulated the high sewage strength in Palestine to low water consumption and people's habits. Raw sewage characteristics are very high according to the sewage strength classification proposed by Metcalf and Eddy [17] and Henze [18] and as compared with sewage characteristics in other countries.

Table 1 Raw wastewater and cesspit septage characteristics of individual home in Beit Dajan/ Palestine

\begin{tabular}{llllll}
\hline \multirow{2}{*}{ Parameters } & Raw & & & Septage & \\
\cline { 2 - 3 } \cline { 5 - 6 } & Range & Average & & Range & Average \\
\hline $\mathrm{pH}$ & $5.8-8.26$ & $7.8(0.7)$ & & $6.66-6.99$ & $6.85(0.1)$ \\
BOD $_{5}$ & $407-512$ & $470.6(38)$ & & $448-527$ & $504(29)$ \\
$\mathrm{COD}$ & $863-1240$ & $995(99)$ & & $1533-1793$ & $1681(107)$ \\
$\mathrm{N}$ total & $111-322$ & $199(54)$ & & $308-378$ & $340(27)$ \\
$\mathrm{PO}_{4}-\mathrm{P}$ & $5.8-15.16$ & $10.45(2.7)$ & & $11.3-16.5$ & $15.11(2)$ \\
$\mathrm{TSS}$ & $304-4952$ & $1290(1314)$ & & $352-2495$ & $1491(998)$ \\
$\mathrm{T}$ & $15-28$ & $22(5)$ & & $19.8-25.6$ & $24.4(2.29)$ \\
$\mathrm{EC}$ & $554-1143$ & $819.4(1143)$ & & $891-1422$ & $1141(170)$ \\
$\mathrm{TDS}$ & $265-552$ & $383(87)$ & & $427-580$ & $499(49)$ \\
\hline
\end{tabular}

All parameters are in ( $\mathrm{mg} / \mathrm{L})$, except $\mathrm{pH}(-)$, EC in $\mu \mathrm{S} / \mathrm{cm}$ and $T$ in ${ }^{\circ} \mathrm{C}$; sampling period $1 / 4 / 2012-25 / 4 / 2012$, \# of raw samples 15, and septage 6 samples; Standard deviations are presented between brackets

Table 2 shows a comparison between the raw sewage characteristics of the studied house in Beit Dajan and several countries in Europe, Africa, Asia and Latin America. but still can be considered of medium strength according to the sewage strength classification proposed by Metcalf and Eddy [17] and Henze [18]. The results show that the Beit Dajan seweage is more concentrated than those presented for other countries. Noticeably that Bei Dajan 
sewage is more concentrated than the sewage in the Egyptian rural areas, and also Turkey. But still, they are les concentrated than the sewage of Al Bierh City/Palestine and Amman in Jordan [16].

Table 2 Sewage characteristics of individual home in Beit Dajan and different cities in different countries and continents

\begin{tabular}{|c|c|c|c|c|c|c|c|c|}
\hline \multirow[t]{2}{*}{ Parameter } & ${ }^{1}$ Palestine & ${ }^{2}$ Palestine & ${ }^{3}$ Jordan & ${ }^{4}$ Egypt & ${ }^{5}$ Turkey & ${ }^{6}$ Netherlands & ${ }^{7}$ Brazil, & ${ }^{8}$ Columbia \\
\hline & $\begin{array}{l}\text { Beit } \\
\text { Dajan }\end{array}$ & Al Bireh & Amman & $\begin{array}{l}\text { Rural } \\
\text { areas }\end{array}$ & Istanbul & Bennekom & $\begin{array}{l}\text { Campina } \\
\text { Grande } \\
\text { Pedregal }\end{array}$ & Cali \\
\hline CODt & 995 & 1586 & 1183 & 824.9 & 410 & 528 & 727 & 267 \\
\hline Nkj-N & 199 & 104 & 109 & 33.8 & 43 & 70 & 44 & 24 \\
\hline Total P & - & 13 & - & 8.9 & 7.2 & 18 & 11 & 1.3 \\
\hline $\mathrm{PO}_{4}{ }^{3-}-\mathrm{P}$ & 10.45 & 12.9 & - & 3.87 & 4.5 & 14 & 8 & - \\
\hline TSS & 1640 & 736 & 420 & 310 & 210 & - & 492 & 215 \\
\hline Temperature & 21.8 & - & $16-24$ & - & - & $20-8$ & $24-26$ & 24.4-25 \\
\hline
\end{tabular}

1, this study; 2, [16]; 3, [19]; 4,[20]; 5,[21]; 6,[22]; 7\&8,[23]. All parameters are in mg/l except: temperature in ${ }^{\circ} \mathrm{C}$.

\subsubsection{BOD, COD and TSS}

Table 3 shows a comparison of constituents present in raw sewage for Beit Dajan and international data. The values of sewage parameters in Beit Dajan are higher than the values reported by EPA, and other studies. The BOD and COD concentrations did not show big daily variation over the measuring period.

Table 3 Comparison of raw sewage range between Beit Dajan (2012) and other studies

\begin{tabular}{llllc}
\hline Parameter & This study & $\begin{array}{l}\text { EPA } \\
(\mathbf{2 0 0 2})\end{array}$ & WERF [27] & $\begin{array}{c}\text { Crites and Tchobanoglous } \\
\text { (1998) }\end{array}$ \\
\hline TSS & $304-4952$ & $155-330$ & $22-1,690$ & $100-350$ \\
BOD $_{5}$ & $407-512$ & $155-286$ & $112-1,101$ & $110-400$ \\
Total Nitrogen & $111-322$ & $26-75$ & $139-4,584$ & $20-85$ \\
Total & $5.8-15.16$ & $6-12$ & $0.2-32$ & $12-20$ \\
Phosphorus & & & & \\
\hline
\end{tabular}

Total Nitrogen and Phosphate

The average value of raw sewage total $\mathrm{N}$ is $199 \mathrm{mg} / \mathrm{L}$, and the range of values is (111-322) $\mathrm{mg} / \mathrm{L}$ (Table 1). The nitrogen concentration is very high as compared with the TN content of municipal seage of Al Bireh City in Palestine, which is clearly due to the very low water consumption. The nitrate concentration in the raw sewage was negligible, and so Total 
Linnaeus ECO-TECH '14,

Kalmar, Sweden, November 24-26, 2014

Nitrogen is coincidently equivalent to Kjeldahl nitrogen. The average value of raw sewage $\mathrm{PO}_{4}-\mathrm{P}$ is $10.45 \mathrm{mg} / \mathrm{L}$ and range of values $(5.8-15.16) \mathrm{mg} / \mathrm{L}$.

\subsubsection{Heavy Metals}

The heavy metals ( $\mathrm{Cu}, \mathrm{Ni}, \mathrm{Pb}, \mathrm{Mn}, \mathrm{Fe}, \mathrm{Cr}, \mathrm{Zn}$ ) concentration in the raw sewage of a one house in Beit Dajan including the average, minimum and maximum values during the research period are depicted in Table 4. Iron (Fe) and Zinc (Zn) have the highest concentration.

Table 4 Heavy metals ( $\mathrm{Cu}, \mathrm{Ni}, \mathrm{Pb}, \mathrm{Mn}, \mathrm{Fe}, \mathrm{Cr}, \mathrm{Zn}$ ) concentration in raw sewage and the cesspit septage of a household in Beit Dajan during the filling period

\begin{tabular}{llllll}
\hline Parameter & \multicolumn{2}{c}{ Raw } & & \multicolumn{2}{c}{ Septage } \\
\cline { 1 - 3 } \cline { 5 - 6 } \cline { 5 - 6 } \cline { 5 - 6 } & Average & Range & & Average & Range \\
$\mathrm{Ni}$ & $0.213(0.081)$ & $0.047-0.328$ & & $0.399(0.170)$ & $0.172-0.652$ \\
$\mathrm{~Pb}$ & $0.000(0.000)$ & $0.000-0.000$ & & $0.038(0.023)$ & $0-0.068$ \\
$\mathrm{Mn}$ & $0.007(0.019)$ & $0.000-0.060$ & & $0.18(0.077)$ & $0.096-0.286$ \\
$\mathrm{Fe}$ & $1.567(0.059)$ & $0.050-0.242$ & & $0.790(0.386)$ & $0.388-1.454$ \\
$\mathrm{Cr}$ & $0.005(0.014)$ & $0.000-0.042$ & & $0.055(0.018)$ & $0.032-0.08$ \\
$\mathrm{Zn}$ & $0.711(0.947)$ & $0.228-4.080$ & & $2.937(0.962)$ & $1.64-4.26$ \\
\hline
\end{tabular}

All parameters are in ppm; Raw sewage: monitored over 15 consecutive days of 24 hours composite samples each (number of samples 15); Sepateg monitored over the whole filling period of 120 days (number of samples 6)

\section{a. Specific waste production}

The calculated specific waste production for the individual home in Beit Dajan in terms of COD, $\mathrm{N}$ and $\mathrm{P}$ are presented in Table 5. In order to obtain a reference waste, the household waste production, source and composition for some countries (Germany, Denmark and Sweden) compiled from several literature sources by Henze [18] are presented in Table 6, in addition to other data for the Dutch society [24], and also from the Al Bireh City in Palestine [16]. is substantially higher than the reference wastes. A comparison based on specific pollution production rates is presented in Table 5. The calculated data show that the specific organic matter in terms of BOD and COD in Beit Dajan individual home wastewater were almost half of the reference wastewaters. This is postulated based on interviews with people to the sociocultural-economical value of very careful discard of any remaining food in dish washing sink. Discarding the remaining food and used cooking oil in kitchen sinks is believed to play a central role in increasing sewage strength in Palestine. Henze [18] showed that the application of 'clean tech cooking' can reduce the COD load of grey water from 55 gCOD/c.d to 32 gCOD/c.d. He reported that kitchen waste contributes around 35\% to the COD content of the household traditional waterborne wastes, and can even be much higher in cases where more solid waste is directed to the sewer system.

Likewise of organic content, the specific P production rate is very low, which reflects low use of detergents, since washing machines and washbasins are significant contributors of orthophosphate in domestic wastewater. The specific $\mathrm{N}$ production is close to the reference 
wastes. It is estimated that around $85 \%$ and $47 \%$ of the waste waterborne $\mathrm{N}$ and $\mathrm{P}$ content originates from urine $[25,26,18]$.

Table 5 Specific production ( $\mathrm{g} / \mathrm{c} . \mathrm{d})$ and composition of wastewater from individual homes in Palestine, NL, and USA and municipal wastewater from Al Bireh/ Palestine

\begin{tabular}{lllll}
\hline Parameter & $\begin{array}{l}\text { Beit Dajan/ } \\
\text { Palestine } \\
\text { (this study) }\end{array}$ & $\begin{array}{l}\text { Al-Bireh/ } \\
\text { Palestine }\end{array}$ & $\begin{array}{l}\text { The Netherlands } \\
{[24]}\end{array}$ & $\begin{array}{l}\text { USA } \\
{[27]}\end{array}$ \\
\hline BOD & 25 & 60 & - & $50-70$ \\
COD & 51 & 170 & 102 & - \\
$\mathrm{N}$ & 10 & 11 & 12.9 & 10.3 \\
$\mathrm{P}$ & 0.54 & 1.4 & 1.7 & 1.7 \\
\hline
\end{tabular}

\section{b. Cesspits septage characteristics}

\subsubsection{General}

The overall septage characteristics assessed in the cesspit of Beit Dajan over the whole measuring period (6 samples from March to July) are presented in Table 1. Sepatge water is relatively concentrated as compared with raw sewage. The septage quality parameters were stable all over the filling period, with the exception of COD and TS that increased with time due to accumulation. Out of the total measured heavy metals $(\mathrm{Cu}, \mathrm{Ni}, \mathrm{Pb}, \mathrm{Mn}$, $\mathrm{Fe}, \mathrm{Cr}, \mathrm{Zn}$ ) over the filling period, Iron (Fe) had the higheset concentration followed by Zinc (Zn).

Table 6 Domestic septage characteristics of Beit Dajan cesspit, Albireh and Ramallah Palestinian cities and USA

\begin{tabular}{ccccc}
\hline Parameter & $\begin{array}{c}\text { Beit Dajan } \\
\text { village/ Palestine } \\
\text { septage }\end{array}$ & $\begin{array}{c}\text { Al Bireh City } \\
\text { /Palestine } \\
\text { raw wastewater }\end{array}$ & $\begin{array}{c}\text { Ramallah city/ } \\
\text { Palestine } \\
\text { raw wastewater }\end{array}$ & $\begin{array}{c}\text { USA } \\
\text { septage }\end{array}$ \\
\cline { 2 - 5 } & This study & {$[16]$} & {$[16]$} & {$[14]$} \\
\hline BOD $_{5}$ & $448-527$ & - & - & $440-78,600$ \\
COD & $1533-1793$ & 1586 & 9180 & $1,500-703,000$ \\
N total & $308-378$ & 104 & - & $66-1060$ \\
TS & $1836-3767$ & - & 729 & $310-930475$ \\
TSS & $352-2495$ & - & - & $353-71402$ \\
TDS & $427-580$ & 7.2 & 17.45 & $1.5-12.6$ \\
pH & $6.66-6.99$ & 13 & 12.8 & $20-760$ \\
$\mathrm{PO}_{4}-\mathrm{P}$ & $11.3-16.5$ & - & - & - \\
EC & $891-1422$ & &
\end{tabular}

All parameters are in (mg/L), except $\mathrm{pH}(-)$ and EC in $\mu \mathrm{S} / \mathrm{cm}$

\subsection{2 $\mathrm{BOD}_{5}, \mathrm{COD}, \mathrm{TS}$ and TDS}

Table 1 shows the average value of $\mathrm{BOD}_{5}$ which is $504 \mathrm{mg} / \mathrm{L}$, and the range of values (448527) $\mathrm{mg} / \mathrm{L}$. These values are not high compared with the septage values from other sources 
Linnaeus ECO-TECH '14,

Kalmar, Sweden, November 24-26, 2014

[14], which are $(440-78,000) \mathrm{mg} / \mathrm{I}$. This comparison entails that the term septage, which was used in EPA data is different from our term as mentioned above. Table 1 shows the average value of COD which is $1681 \mathrm{mg} / \mathrm{L}$, and the range of values which is (1533-1793) $\mathrm{mg} / \mathrm{l}$. The high COD/BOD ratio indicate that septage is of poor biodegradability due to already removal of easily biodegradable matter in through the anaerobic processes in the cesspit. The D.O. in the septage inside the cesspits was "zero". Nonetheless, the BOD value of 504 is still high and will impose a threat to the environment, and will resemble a load to the existing wastewater treatment plants.

Samples from the cesspit have high concentrations of TSS, and TDS. Table 1shows the average values of these parameters of 2295 and $499 \mathrm{mg} / \mathrm{L}$, respectively. The results revealed increase in solids concentration with time due to accumulation.

\subsubsection{Total Nitrogen and phosphate}

The average value of total $\mathrm{N}$ is $337.67 \mathrm{mg} / \mathrm{L}$, and the range of values is $(308-378) \mathrm{mg} / \mathrm{L}$ (Table 1). The average value of Ortho-phosphate $\left(\mathrm{PO}_{4}-\mathrm{P}\right)$ is $15.11 \mathrm{mg} / \mathrm{L}$ and range of values (11.3-16.5) $\mathrm{mg} / \mathrm{L}$. Washing machines and washbasins are significant contributors of orthophosphate in domestic wastewater. The nitrogen content is quite high due to ammonificaton processes inside the cesspit. The nitrohen load from a cesspit either to nature, once disposed in open areas, or to a treatment plant, is clearly of big concern. On a one hand the oxygen equivalent to this nitrogen content is around $1500 \mathrm{mg} / \mathrm{L}$. Moreover, such high nitrogen content might consume the wastewater alkalinity during the nitrification process that produces $\mathrm{H}^{+}$, and so attention should be given to nitrogen load from septage originating from localities with low water consumption.

\subsubsection{Heavy metals of cesspit septage}

The heavy metals $(\mathrm{Cu}, \mathrm{Ni}, \mathrm{Pb}, \mathrm{Mn}, \mathrm{Fe}, \mathrm{Cr}, \mathrm{Zn})$ concentration in the septage from the cesspit in Beit Dajan including the average, minimum and maximum values during the filling period are presented in Table 7. It was found that Iron (Fe) has the highest concentration as compared with other metals. The high Fe concentration in septage water is most likely due to solubilisation of iron from the ferric form to ferrous under the reduced anaerobic conditions.

The reference guiding and standard values presented in Table 7 reveal that septage water content of the heavy metals $\mathrm{Cu}, \mathrm{Pb}, \mathrm{Mn}, \mathrm{Fe}$ and $\mathrm{Zn}$ is not in compliance with heavy metals concentration limits according to the Palestinian regulations for wadi disposal and effluent reuse in agriculture. This entails that septage disposal in wadi and agricultural fields is not safe. Differently, Al-Bireh municipal effluent of an extended aeration plant can be considered safe, with slight exception of $\mathrm{Cu}$ that is almost at the limit for Palestinian standards and FAO guidelines. Although the raw sewage of Al-Bireh contains higher heavy metal concentrations.

The sewerage by- law of Al-Bireh municipality (for the year 2000) has specified an obligatory guidelines for industrial effluent quality. By this law, pollutants concentration in this effluent shall not exceed the identified limits, the limits of maximum allowed heavy metals concentrations in industrial effluent are shown in Table 7. According to this regulations, septage 
Linnaeus ECO-TECH '14,

Kalmar, Sweden, November 24-26, 2014

heavy metals concentrations allow the disposal of septage in Al-Bireh wastewater treatment plant septage receiving unit to be further treated in the aerobic system.

Table 7 Comparison of heavy metals ( $\mathrm{Cu}, \mathrm{Ni}, \mathrm{Pb}, \mathrm{Mn}, \mathrm{Fe}, \mathrm{Cr}, \mathrm{Zn}$ ) in raw sewage and septage of Beit Dajan cesspit Al Bireh City raw sewage and treated effluent in extended aeration system with Palestinian standards and technical specifications and FAO

\begin{tabular}{|c|c|c|c|c|c|c|c|c|c|}
\hline & & $\mathrm{Cu}$ & $\mathrm{Ni}$ & $\mathrm{Pb}$ & $\mathrm{Mn}$ & $\mathrm{Fe}$ & $\mathrm{Cr}$ & $\mathrm{Zn}$ & Reference \\
\hline \multirow{2}{*}{$\begin{array}{c}\text { Raw sewage (Beit } \\
\text { Dajan) }\end{array}$} & Avg & 0.213 & 0.000 & 0.007 & 0.115 & 1.567 & 0.005 & 0.711 & This study \\
\hline & Max & 0.328 & 0.000 & 0.060 & 0.242 & 4.60 & 0.042 & 4.080 & This study \\
\hline \multirow{2}{*}{ Septage (Beit Dajan) } & Avg & 0.399 & 0.038 & 0.180 & 0.790 & 23.680 & 0.055 & 2.937 & This study \\
\hline & Max & 0.652 & 0.068 & 0.286 & 1.454 & 36.4 & 0.08 & 4.26 & This study \\
\hline \multirow{2}{*}{$\begin{array}{l}\text { Al Bireh city raw } \\
\text { sewage }\end{array}$} & Avg & 0.221 & 0.075 & N/A & N/A & N/A & 0.163 & 1.364 & [28] \\
\hline & Max & 0.72 & 0.117 & N/A & N/A & N/A & 0.227 & 3.496 & [28] \\
\hline \multirow{2}{*}{$\begin{array}{l}\text { Al Bireh city treated } \\
\text { effluent system }\end{array}$} & Avg & 0.11 & 0.03 & N/A & N/A & N/A & 0.057 & 0.478 & [28] \\
\hline & Max & 0.207 & 0.047 & N/A & N/A & N/A & 0.089 & 1.480 & [28] \\
\hline $\begin{array}{l}\text { Palestinian standards/ } \\
\text { discharge of treated } \\
\text { sewage to wadis }\end{array}$ & & 0.200 & 0.200 & 0.100 & 0.200 & 2.000 & 0.500 & 5.000 & [29] \\
\hline $\begin{array}{l}\text { Palestinian technical } \\
\text { specifications for } \\
\text { agricultural use / Type } \\
\text { D (lowest standards) } \\
\text { discharge of treated } \\
\text { sewage to wadis }\end{array}$ & & 0.200 & 0.200 & 0.200 & 0.200 & 5.000 & 0.100 & 2.000 & [30] \\
\hline $\begin{array}{l}\text { Maximum heavy } \\
\text { metals to be } \\
\text { discharged in the } \\
\text { public sewerage } \\
\text { system }\end{array}$ & & 1.000 & 1.000 & 0.400 & 1.000 & N/A & 0.500 & 50.000 & [31] \\
\hline $\begin{array}{l}\text { FAO guidelines for } \\
\text { maximum } \\
\text { recommended heavy } \\
\text { metals concentration }\end{array}$ & & 0.200 & 0.200 & 5.000 & 0.200 & 5.000 & 0.100 & 2.000 & [32] \\
\hline
\end{tabular}

All values are in ppm; N/A: not available

\subsubsection{Fecal Coliform}

Fecal Coliform bacteria are found in both sewage and septage analyzed samples which was 6.70E+07 CUF/100mL and $8.40 \mathrm{E}+06 \mathrm{CUF} / 100 \mathrm{~mL}$, respectively. This shows that the number of the Fecal Coliform bacteria had decreased in the cesspit as a result of unsuitable conditions. 


\subsubsection{Relationship between the COD and BOD values in wastewater}

The ratio of COD: BOD of influent sewage and effluent wastewater in this study exhibited a ratio ranging from about 2.1-2.4 and 2.95-3.88 respectively and the values are comparable to those presented by Metcalf and Eddy [17, 33] (Table 8). The typical COD: BOD $_{5}$ ratio of domestic wastewaters is usually in the range 1.25 to 2.5. However, for treated effluents, it ranged from 3.357 to 9.655. This indicates relatively higher proportion of the no biodegradable content in treated effluent than raw wastewater, or treated sewage in anaerobically in UASB reactors [4].

Table 8 The COD, BOD, $N$ and $P$ ratios in raw sewage and cesspit septage in Beit Dajan

\begin{tabular}{lllll}
\hline & \multicolumn{2}{c}{ Raw sewage } & \multicolumn{2}{c}{ Septage } \\
\cline { 2 - 5 } & Average & Range & Average & Range \\
\hline COD:BOD & $2.12(0.2)$ & $1.75-2.47$ & $3.35(0.34)$ & $2.95-3.88$ \\
N:BOD & $0.4(0.11)$ & $0.22-0.64$ & $0.67(0.05)$ & $0.59-0.79$ \\
N:COD & $0.2(0.05)$ & $0.11-0.3$ & $0.20(0.01)$ & $0.19-0.23$ \\
N:P & $19.57(4.62)$ & $10.49-25.90$ & $22.76(4.02)$ & $18.66-30.07$ \\
\hline
\end{tabular}

Table 9 The COD, BOD, $N$ and $P$ ratios in different places and systems

\begin{tabular}{llllll}
\hline & $\begin{array}{l}\text { Raw Sewage } \\
\text { Beit Dajan }\end{array}$ & $\begin{array}{l}\text { Septage } \\
\text { Beit Dajan }\end{array}$ & $\begin{array}{l}\text { Raw } \\
\text { Al- } \\
\text { Bireh }\end{array}$ & $\begin{array}{l}\text { UASB septic } \\
\text { tank 2d }\end{array}$ & $\begin{array}{l}\text { UASB } \\
\text { septic tank } \\
\text { 4d }\end{array}$ \\
\hline & This study & This study & {$[16]$} & {$[4]$} & {$[4]$} \\
\hline COD: BOD & 2.12 & 3.35 & 2.05 & 2.22 & 2.13 \\
N:BOD & 0.4 & 0.67 & 0.13 & 0.25 & 0.28 \\
N:COD & 0.2 & 0.2 & 0.07 & 0.12 & 0.15 \\
N:P & 19.57 & 22.76 & 6.23 & 4.22 & 4.21 \\
\hline
\end{tabular}

Table 11 shows a comparison between different ratios in this study and several places and systems beside raw sewage and septage in Beit Dajan.

The high N:P ratio might be due to socio-cultural reasons, viz. low use of detergents, as well as wastewater disposal methods, viz. partly disposal of dish washing water in the garden. However, these ratios are in compliance with N/P ratios calculated for different countries, Brazil, Egypt, Turkey, etc, as presented in Metcalf and Eddy [33]. 
Linnaeus ECO-TECH '14,

Kalmar, Sweden, November 24-26, 2014

Table 12 Household raw sewage and septage characteristics in Beit Dajan and Al Bireh city wastewater characteristics and UASB-septic tank treating domestic sewage in Palestine under ambient conditions

\begin{tabular}{|c|c|c|c|c|c|}
\hline & \multicolumn{2}{|c|}{$\begin{array}{c}\text { Household } \\
\text { Raw and septage }\end{array}$} & \multicolumn{2}{|c|}{$\begin{array}{c}\text { Municipal } \\
\text { Raw and treated }\end{array}$} & \multirow{2}{*}{$\begin{array}{c}\text { Septage } \\
\text { Al-Bireh } \\
\text { City }\end{array}$} \\
\hline & $\begin{array}{c}\text { Beit } \\
\text { Dajan } \\
\text { household } \\
\text { influent } \\
\text { sewage } \\
\end{array}$ & $\begin{array}{c}\text { Beit } \\
\text { Dajan } \\
\text { septage } \\
\text { water }\end{array}$ & $\begin{array}{l}\text { Al Bireh raw } \\
\text { sewage }\end{array}$ & $\begin{array}{c}\text { Effluent } \\
\text { UASB-septic } \\
\text { tank (HRT = } \\
2 \text { days) }\end{array}$ & \\
\hline & $\begin{array}{l}\text { This } \\
\text { study }\end{array}$ & $\begin{array}{l}\text { This } \\
\text { study }\end{array}$ & [34] & [34] & [7] \\
\hline COD Total & 995(99) & 1681(10) & $905(254)$ & $433(109)$ & 1034 \\
\hline Dissolved & & & $350(124)$ & 265(96) & \\
\hline $\mathrm{NH}_{4}^{+}$as $\mathrm{N}$ & ${ }^{+++} 199(54$ & ${ }^{+++} 340(2)$ & $39.2(18)$ & $35.6(20.7)$ & 83 \\
\hline $\mathrm{N}$ total & ) & & ${ }^{++} 70(10)$ & $58(7.5)$ & \\
\hline $\mathrm{PO}_{4}{ }^{3-}$ as $\mathrm{P}$ & $10.45(2.7)$ & $15.11(2)$ & $8.4(4.1)$ & $12.3(1.8)$ & 12 \\
\hline TSS & 1290(131) & 1491(99) & ${ }^{+} 1125(631)$ & $44.7(29)$ & 3068 \\
\hline $\begin{array}{l}\text { Faecal } \\
\text { coliform }\end{array}$ & $6.71 \mathrm{E}+07$ & $8.4 \mathrm{E}+06$ & $\begin{array}{l}{ }^{+} 8.40 \mathrm{E}+09 \\
(4.5 \mathrm{E}+09) \\
\end{array}$ & $\begin{array}{c}{ }^{+} 3.37 \mathrm{E}+07 \\
(2.51 \mathrm{E}+07))\end{array}$ & \\
\hline
\end{tabular}

Standard deviations are shown in parenthesis; all parameters are in mg/L except: faecal coliform: CFU/100 $\mathrm{ml} ;{ }^{+}$[35]; ${ }^{++} \mathrm{NKj} ;{ }^{+++} \mathrm{N}$ total is coincidently equivalent to $\mathrm{NKj}$ since $\mathrm{NO}_{3}$ concentration was negligible.

\section{c. Daily pollutant contribution/ pollution fluxes}

The results of this study revealed that the specific BOD load in the raw sewage of Beit Dajan is 25 gram/cap/day and 5.6 gram/cap/day in the cesspit emptied septage (Table 8).

Table 8 Specific pollutant contribution of Beit Dajan household (2012) and removal in the cesspit

\begin{tabular}{ccccc}
\hline Parameter & Raw Sewage & Septage & \multicolumn{2}{c}{ Removal } \\
\cline { 2 - 5 } & g/c/d & g/c/d & g/c.d & $\%$ \\
\hline Total N & 10 & 4.8 & 5.2 & 52 \\
BOD & 25 & 5.6 & 19.4 & 78 \\
CODt & 51 & 19.3 & 31.7 & 62 \\
PO $_{4}-\mathrm{P}$ & 0.51 & 0.17 & 0.34 & 66 \\
TSS & 83 & 25.5 & 57.5 & 69 \\
\hline
\end{tabular}

The reduction in the specific $\mathrm{P}$ and $\mathrm{N}$ between the raw and septage waters is partly attributed to possible ammonia and phosphate precipitation through complex formation, e.g. precipitation of ammonium as struvite $\left(\mathrm{MgNH}_{4} \mathrm{PO}_{4}{ }_{6} 6 \mathrm{H}_{2} \mathrm{O}\right)$ [36, 37]. Precipitation of struvite is a common phenomenon in anaerobic treatment of both wine distillery and piggery waste waters, and also sludge waste derived from excess biological phosphate removal systems. The reason for this is 
Linnaeus ECO-TECH '14,

Kalmar, Sweden, November 24-26, 2014

that these wastes contain higher than usual concentrations of dissolved ortho-phosphates, free and saline ammonia and magnesium ions and these species form the components of mineral struvite [38]. Based on the chemical structure of struvite $\left(\mathrm{MgNH}_{4} \mathrm{PO}_{4}{ }_{-} 6 \mathrm{H}_{2} \mathrm{O}\right)$ and the molar fractions of $\mathrm{N}$ and $\mathrm{P}$ and assuming that all removed $\mathrm{P}(0.34 \mathrm{~g} / \mathrm{c} . \mathrm{d})$, the maximum possible $\mathrm{N}$ removal is 0.15 g.c.d. This amount of possibly bound $\mathrm{N}$ in the form of struvite represents less than $3 \%$ of the removed $\mathrm{N}$ (Table 8). So, the vast majority of $\mathrm{N}$ removed will most likely travel out of the cesspit into the surrounding soil, but hard to predict that the amount that might reach the groundwater or adsorbed onto soil. Considering specific influent COD which is $51.2 \mathrm{~g} / \mathrm{c} / \mathrm{d}$ and the specific effluent COD is $18.7 \mathrm{~g} / \mathrm{c} / \mathrm{d}$ then the lost COD represent $32.5 \mathrm{~g} / \mathrm{c} / \mathrm{d}$, which is a potential source of green gas emissions in the form of mainly $\mathrm{CH}_{4}$ and also $\mathrm{CO}_{2}$.

The data presented in Table 9 reveal that the specific water consumption is $59 \mathrm{~L} / \mathrm{c} / \mathrm{d}$ and they have a few plants around their home. The specific wastewater production is $51.5 \mathrm{~L} / \mathrm{c} / \mathrm{d}$, which resembles $87 \%$ of the consumed water. On other hand, the emptied septage from the cesspit $11 \mathrm{~L} / \mathrm{c} / \mathrm{d}$ which indicate that the total percolated wastewater to surrounding soil was $40 \mathrm{~L} / \mathrm{c} /$ day.

Table 9 Specific water consumption and specific septage water infiltration and desludged and percentages out of consumed water in Beit Dajan (2012)

\begin{tabular}{lllll}
\hline & $\begin{array}{l}\text { water } \\
\text { consumption }\end{array}$ & $\begin{array}{l}\text { WW } \\
\text { generated }\end{array}$ & $\begin{array}{l}\text { Septage } \\
\text { desludge }\end{array}$ & $\begin{array}{l}\text { Septage } \\
\text { infiltrated }\end{array}$ \\
\hline $\begin{array}{l}\text { Specific waste(water) } \\
\text { (L/c.d) }\end{array}$ & 59 & 51.5 & 11 & 40 \\
$\%$ of water consumption & $100 \%$ & $87 \%$ & $19 \%$ & $68 \%$ \\
\hline
\end{tabular}

\section{CONCLUSIONS}

The results of this study reveal that raw wastewater characteristics of individual home in Beit Dajan is of medium strength and is relatively less concentrated than municipal, sewage. Sepatge water is relatively concentrated as compared with raw sewage. Septage water content of the heavy metals $\mathrm{Cu}, \mathrm{Pb}, \mathrm{Mn}, \mathrm{Fe}$ and $\mathrm{Zn}$ is not in compliance with heavy metals concentration limits according to the Palestinian regulations for wadi disposal and effluent reuse in agriculture. This entails that septage disposal in wadi and agricultural fields is not safe. However, according to municipal regulations, septage heavy metals concentrations allow the disposal of septage in Al-Bireh wastewater treatment plant septage receiving unit to be further treated in the aerobic system. The vast majority of $\mathrm{N}$ removed will most likely travel out of the cesspit into the surrounding soil, and might potentially reach the groundwater.

The objective of this study was to characterize the wastewater in the partially sealed cesspits and to indentify and quantify the pollution fluxes from this specific type of cesspits. Based on the results of the study, the following conclusions were drawn: 
Linnaeus ECO-TECH '14,

Kalmar, Sweden, November 24-26, 2014

$>$ Cesspit wastewater in the target area is concentrated as compared with raw wastewater.

$>$ Cesspit wastewater in the target area are considered as high strength domestic sewage, with a CODtot concentration of $1681 \mathrm{mg} / \mathrm{L}$ and the average BOD5 and TSS concentrations were 504 and $2064 \mathrm{mg} / \mathrm{L}$, respectively.

$>$ The total pollution fluxes from the targeted cesspit were $7.6 \mathrm{~m}^{3}$ per month.

$>$ Daily water consumption was $0.823 \mathrm{~m}^{3}$ per day.

$>$ The result obtained in this study showed that the heavy metals concentrations in the wastewater were within the acceptable rang according to the previous studies, and the Iron (Fe) and Zinc (Zn) have the highest concentration.

$>$ The daily pollutant contribution of COD was 51.2 gram/cap/day.

$>$ The values of septage parameters in Bet Dajan cesspit are lower than that the values of EPA septage parameters, as the septage in the target cesspit from this type partially sealed cesspits, where short hydraulic retention time prevailed in cesspits leading to weak anaerobic processes. Hence, the liquid material (supernatant) in the cesspit is septage water and not a real septage. The septage in Beit Dajan cesspit has almost similar municipal wastewater characteristics.

\section{ACKNOWLEDGMENTS}

This study was carried out under the framework of the UNESCO-IHE UWIRA project of which Birzeit University is a partner. This project is financially supported by the Dutch Government (DGIS) under UNESCO-IHE Partnership Research Fund (UPaRF).

\section{REFERENCES}

[1] Nyenjea P.M., Foppen J.W., Kulabako R. and Muwanga A., Uhlenbrook. S. 2013. Nutrient pollution in shallow aquifers underlying pit latrines and domestic solid waste dumps in urban slums. Journal of Environmental Management 122, 15-24.

[2] Scandura J.E. and Sobsey M.D., 1997. Viral and bacterial contamination of groundwater from onsite sewage treatment systems. Water Science and Technology 35 (11/12), 141-146.

[3] Luostarinen S.A. and Rintala J.A., 2005. Anaerobic on-site treatment of black water and dairy parlour wastewater in UASB-septic tanks at low temperatures. Water Research 39 (2-3), 436448.

[4] Al-Shayah M. and Mahmoud N., 2008. Start-up of an UASB-septic tank for community on-site treatment of strong domestic sewage. Bioresource Technology 99, 7758-7766.

[5] PCBS, Palestinian Central Bureau of Statistics (2009). Population, Housing and Establishment: Census 2012. Al-Bireh, West Bank, Palestine.

[6] PWA, 2012. Annual water status report 2011. Palestinian Water Authority (PWA). December, 2012.

[7] Hithnawi T., 2004. Septage characterization and impact assessment on the treatment efficiency of Albireh sewage treatment plant. MSc thesis, Birzeit University, Palestine.

[8] Voigtländer G., Ruhland G. and Diel M., 1996. Fäkalien und Fäkalschlämme in unterbelsteten Kläranlagen - Siebtes Gemeinsames Seminars Abwassertechnik in Weimar- Hrg. WARFörderverein der Technischen Universitäte Darmstadt. 
[9] MacFarlane G.R. and Burchett M.D., 2000. Cellular distribution of $\mathrm{Cu}, \mathrm{Pb}$ and $\mathrm{Zn}$ in the Grey Mangrove Avicennia marina (Forsk.). Vierh. Aquat. Bot. 68, 45-59.

[10] Loska, K. and Wiechula D., 2003. Application of principal component analysis for the estimation of source heavy metal contamination in surface sediments from Rybnik Reservoir Chemosphere 51, 723-733.

[11] Dudka S. and Miller W.P., 1999. Permissible Concentrations of Arsenic and Lead in Soils Based on Risk Assessment. Journal of Water, Air, \& Soil Pollution 113, 127-132.

[12] Sorme L. and Lagerkvist R., 2002. Sources of heavy metals in urban wastewater in Stockholm. Science of the Total Environment 298, 131-145.

[13] ATV- A 123E., 1985. Treatment and Disposal of Sludge from Small Sewage Treatment Plants. GERMAN ATV RULES AND STANDARDS. GERMAN ASSOCIATION FOR THE WATER ENVIRONMENT

[14] U.S. EPA, 1994. Guide to Septage Treatment and Disposal. EPA Environmental Protection. Agency. Washington, D.C., EPA Number: 625R94002.

[15] Tahboub M., 1999. Evaluation of wastewater treatment alternatives for Hebron City. M.Sc. Thesis, Faculty of Graduate Studies, Birzeit University, Birzeit, West Bank, Palestine.

[16] Mahmoud N., Amarneh M. N., Al-Sa'ed, R. Zeeman G., Gijzen H. and Lettinga G., 2003. Sewage characterization as a tool for the application of anaerobic treatment in Palestine. Environmental Pollution 126(1), 115-122.

[17] Metcalf \& Eddy. 1991. Wastewater Engineering: Treatment, Disposal, and Reuse. Third Edition. Irwin Mac Graw-Hill, New York. p. 109.

[18] Henze M., 1997. Waste design for households with respect to water, organics and nutrients. Water Science \& Technology 35 (9), 113-120.

[19] Kerstens, S., 2001. Anaerobic wastewater treatment of strong sewage, one stage and two stage systems, MSc thesis, Department of Environmental Technology, Wageningen University, Wageningen, The Netherlands.

[20] Tawfik A., 1998. Wastewater Treatment for Rural Areas and Small Communities and Reuse for Irrigation and Aquaculture. MSc thesis, Tanta University, Egypt.

[21] Orhon D., Ateo E., Sözen S. and Çokgör E.U., 1997. Characterization and COD fractionation of domestic wastewaters. Environmental Pollution 95 (2), 191-204.

[22] Elmitwalli T., 2000. Anaerobic treatment of domestic sewage at low temperature. PhD thesis, Department of Environmental Technology, Wageningen University, Wageningen, The Netherlands.

[23] Haandel van A.C. and Lettinga G., 1994. Anaerobic Sewage Treatment. A Practical Guide for Regions with a Hot Climate. John Wiley and Sons, New York.

[24] Kujawa-Roeleveld K., Zeeman G. and Lettinga G., 2000. DESAH in grote gebouwen. EETKIEM nr 98115 rapport (in Dutch).

[25] Zeeman G. and Lettinga G., 2001. Objectives of DESAR-Decentralised Sanitation and Reuse. 30. Abwassertechnisches Seminar 13. DECHEMA-Fachgespra“ ch Umweltschutz DESAR Kleine Kla“ ranlagen und Wasserwiederverwendung. Berichte aus Wassergu " te- und Abfallwirtschaft. Technische Universita“t Mu“ nchen, Germany.

[26] Henze M. and Ledin A., 2001. Types, characteristics and quantities of classic, combined domestic wastewaters. In: Decentralised Sanitation and Reuse; Concepts, systems and implementation. Eds. Piet Lens, Grietje Zeeman \& Gatze Lettinga. IWA publishing. 
[27] WERF, 2007. Influent constituents characteristics of the modern waste stream from single sources: Literature review. Published by The water environment Research Foundation, in cooperation with IWA publishing.

[28] Samara N. M., 2009. Heavy metals concentration in biosolids of Al-Bireh sewage treatment plant and assessment of biosolids application impacts on crops growth and productivity. MSC thesis, Birzeit University, Palestine.

[29] PSI, 2003. Treated wastewater standards 742-2003. Palestinian standards institution

[30] Technical specifications, 2012. Palestinian compulsory technical specifications for wastewater reuse 34-2012.

[31] Al Bireh Municipality, 2000. The sewerage by law of Al Bireh municipality.

[32] FAO, 1992. Wastewater treatment and reuse in Agriculture, Agricultural use of sewage sludge. Food and Agricultural Organization of the United Nations (FAO) corporate document prosperity, Rome, Italy.

[33] Metcalf and Eddy, Inc., 2003. Wastewater Engineering: Treatment and Reuse, fourth ed. McGraw Hill, New York.

[34] Al-Jamal W. and Mahmoud N., 2009. Community onsite treatment of cold strong sewage in a UASB-septic tank. Bioresource Technology 100, 1061-1068.

[35] Mahmoud N. and van Lier J. B., 2011. Enhancement of an UASB-septic tank performance for decentralised treatment of strong domestic sewage. Water Science \& Technology 64(4), 923929.

[36] Mamals D, Pitt PA, Cheng YW, Loianco J, Jenkins D. Determination of ferric chloride dose to control struvite precipitation in anaerobic sludge digesters. Water Environ Res., 66, 912-8.

[37] Mahmoud N., Zeeman G., Gijzen H. and Lettinga G., 2004. Anaerobic stabilisation and conversion of biopolymers in primary sludge: effect of temperature and sludge retention time. Water Research 38(4), 983-991.

[38] Loewenthal R. E., Kornmüller U. R. C. and van Heerden E. P., 1994. Modelling struvite precipitation in anaerobic treatment systems. Water Science \& Technology 30(12), 107-116. 